\title{
Transmission of World Prices to the Vietnamese Economy
}

\author{
Philip Abbott \\ Purdue University, West Lafayette, USA \\ $\mathrm{Ce} \mathrm{Wu}$ \\ Indiana Wesleyan University, Marion, USA \\ Finn Tarp \\ UNU World Institute for Development Economics Research (UNU-WIDER), Helsinki, Finland
}

\begin{abstract}
International economic integration has been a central policy goal for the Vietnam government since the doi moi reform was initiated in 1986. We explore the Vietnamese increasing integration into the world market and bouts of high inflation. Five price transmission models using three levels of sectoral aggregation, examine the transmission of world price shocks to the Vietnamese domestic market and the impact of inflation on domestic prices from 1999 to 2008. Empirical results find wide sectoral variation, imperfect price transmission, non-neutral inflation pass-through, the dominant effect of inflation on domestic prices, and a low speed of adjustment to the Law of One Price. We conclude that policy analysts need disaggregated sector-level price transmission elasticities for accurate trade policy analysis and that careful attention must be paid to how inflation influences the economy. Moreover, while tariff reforms have typically been focused in many studies to come to grips with policy outcomes, the key to such
\end{abstract}

\footnotetext{
* Corresponding Author: Philip Abbott; Department of Agricultural Economics, Purdue University Krannert Building, 403 West State Street, West Lafayette, IN 47907-2056, USA; E-mail: abbottpc@purdue.edu.

Co-Author: Ce Wu; School of Business and leadership, Indiana Wesleyan University, Marion, IN 46953, USA; E-mail: ce.wu2012@gmail.com,

Finn Tarp; UNU World Institute for Development Economics Research (UNU-WIDER) Katajanokanlaituri 6 B, FI-00160, Helsinki, Finland; E-mail: Finn.Tarp@econ.ku.dk.
} 
understanding should be more associated with institutional reforms, market access, and incentives for foreign investment.

JEL Classification: F13, F14, O24, O53

Keywords: Price Transmission, Market Integration, Inflation, Vietnam

\section{Introduction}

High inflation was a persistent problem for Vietnam in the 1980s. Inflation came under control in the mid-90s, remaining at less than 10\% per year; however in 2008 it rose again to $23 \%$ (IMF 2011). This surge in inflation was related, among other things, to World Trade Organization (WTO) accession and the large current account deficit following significant inflows of trade and foreign capital (Riedel 2009). The worldwide great recession and the collapse of world trade brought inflation in Vietnam back down to $7 \%$ in 2009 , yet it rose to $9 \%$ in 2010 (IMF 2011) and has remained an issue since (Abbott and Tarp 2012).

The International Monetary Fund (IMF) (2006) has argued that greater market integration and foreign competition, coming as part of globalization, should restrain inflation. A core premise of most traditional trade policy analysis, and the IMF logic, is that price signals are fully transmitted both spatially and across borders. Yet, price transmission, the extent to which world price changes are transmitted to domestic prices, may be imperfect. Markets are often segmented due to high transaction costs, imperfect competition, or because trade policy interventions block the influence of world prices on the domestic market. A key aim of this study is to explore the relationship between border and domestic prices in Vietnam to establish whether and how much inflation resulting from domestic or international causes, or pricing in foreign markets, is influential in determining the evolution of domestic prices.

Alternative econometric model specifications are employed at several levels of disaggregation to estimate the extent of world price transmission versus effect of inflation on domestic prices. Results are used to investigate hypotheses on the degree of market integration, aggregation bias in estimation of price transmission elasticities, adjustment speed of domestic prices to world price changes, and neutrality of inflation. 
The remainder of the study is structured as follows. Section II gives brief historical background on Vietnam's economy. Section III reviews recent price transmission literatures and considers Vietnam as a case. Section IV lays out the specifications of the various alternative models employed to analyze the data. Section V discusses data sources and various aggregation strategies. Section VI presents our results and hypothesis tests on market integration or segmentation, dynamic price adjustment, and inflation neutrality. Section VII concludes.

\section{Historical Background}

The Indochina war and conflicts from 1954 to 1975 left the economy of Vietnam severely damaged. The government of the unified country was faced with a massive need for reconstruction and development. Central planning was adopted for the management of the economy and the allocation of resources, and political and economic integration of the North and South became an important goal. However, planned targets were not achieved and lack of food and consumer goods became widespread. The Third FiveYear Plan, covering 1981 to 1985, adopted a more pragmatic approach to policy making and some efforts were made to decentralize economic planning. Yet, it was only in 1986 that the government embarked on a comprehensive program of political and economic reforms. This became known as doi moi and was intended to facilitate renovation and a general transition to what was referred to as a socialist-oriented market economy.

Doi moi combined central planning with market incentives that encouraged the establishment of private enterprises and inflows of foreign direct investment. The economy started recovering, and in the late 1990s and early 2000s, Vietnam rapidly expanded its global presence. After two-decades of reform, including numerous trade agreements, Vietnam had become one of the fastest growing economies in the world. Average annual Gross Domestic Product (GDP) growth reached no less than 7.3\% from 2000 to 2009, 3.9\% faster than East Asia and the Pacific region average and 4.9\% faster than the world average (World Bank 2012). Trade (imports plus exports) as a share of GDP reached $178 \%$ by 2008 (GSO 2011). More importantly, growth was translated into macroeconomic stability and significant poverty reduction (World Bank 2013).

Doi moi and subsequent trade policy reforms also resulted in much greater economic 
integration with world markets, culminating in Vietnam's accession to the WTO in 2007. Major cost of opening the Vietnamese economy was renewed inflationary pressure. The worldwide great recession and collapse of world trade brought inflation in Vietnam back down to $7 \%$ in 2009 , yet it rose afterwards and has remained an issue as Vietnam utilized various stimulus measures to sustain economic growth and poverty reduction. (Abbott and Tarp 2012).

\section{Price Transmission}

\section{A. Literature review}

Price transmission has been investigated from a number of perspectives. Early studies emphasized the role of endogenous trade policy, motivated by variable levies in the European Union (EU) (Abbott 1979, Bredahl, Collins, and Myers 1979). More recent analysis has focused on tests of market integration for a specific domestic market, particularly agricultural markets (Abdulai 2002, Fafchamps and Hill 2008, Goodwin and Holt 1999, Kinnucan and Forker 1987, Miller and Hayenga 2001, von CramonTaubadel 1998). Others have taken a macroeconomic perspective, measuring the extent of exchange rate pass-through on aggregate price indices (Athukorala and Menon 1994, Knetter 1995, Goldberg and Knetter 1999, Menon 1995). They have also emphasized imperfect competition in the pricing to market model (Atkeson and Burstein 2008, Krugman 1987, Marston 1990), foreign currency contracting (Gopinath, Itskhoki, and Rigobon 2010), and high transactions costs (Anderson and Wincoop 2004). Both groups have found frequent violations of the Law of One Price (LOP), a concept which posits that goods must sell for the same price in all locations. (Alessandria 2004, Giovannini 1988, Isard 1977, Knetter 1995, Milnovic 1998, Richardson 1978, Rogoff et al. 2001).

While imperfect price transmission was at one time a key element of trade models (Tyers and Anderson 1992), such studies and the associated relationship with policy analysis are now relatively scarce. Baffes and Gardner (2003) estimated dynamic price relationships, observing that agricultural markets in a developing country often remain segmented after trade liberalization following IMF conditionality. Nicita (2009) recently demonstrated the importance of taking price transmission directly into account 
to determine the extent of poverty reduction from trade liberalization in a general equilibrium framework. Measuring price transmission has also been important for understanding the effects of high commodity prices on developing economies during the 2007 and 2008 food crisis (FAO 2011, Headey and Fan 2010).

Modern Computable General Equilibrium (CGE) models do not ignore the price transmission issue. A different approach is invoked, however, assuming domestic and imported goods are imperfect substitutes following an Armington or nested Constant Elasticity of Substitution (CES) specification. Two level of imperfect substitution are typically assumed - substitution across import suppliers (the original Armington model) and substitution between domestic and foreign goods. Historically, the values of the Armington substitution elasticities used in CGE models were simply assumed (Abbott et al. 2009). Some recent efforts have estimated substitution across import suppliers, but Hillberry and Hummels (2012) observe that estimating the foreign-domestic substitution elasticity has been both rare and problematic from an econometric perspective. This latter parameter is crucial for capturing imperfect price transmission, and must also address aggregation issues and the possibility of non-tradable goods in an aggregate category (Bautista et al. 1998). Furthermore, if relatively large values typically assumed in calibrated models do not allow for imperfect price transmission, predictions of market access and the impact of tariff changes are likely to be overestimated.

Many studies have attempted to predict the consequences of Vietnam's accession to the WTO (Abbott et al. 2009, Rama and Sa 2005), and subsequently trade liberalization. Such analyses have typically involved a CGE model with no explicit consideration of imperfect price transmission, and with assumed rather than estimated substitution elasticities. Importantly, trade policy includes much more than tariff changes such as institutional reform, market access openings, and incentives to foreign investment. Modeling efforts to establish trade policy impacts have, however, typically focused on changes in tariff commitments, if not exclusively, at least as one critically important mechanism, and so rely on strong linkages between world and domestic prices.

\section{B. Vietnam}

In Vietnam, casual observation suggests that domestic and international sectoral prices are not highly correlated. For the 87 tradable sectors among the 112-sector aggregation used by the General Statistics Office (GSO), the average correlation between 
domestic prices and border prices (measured in home currency with tariffs included) is only 0.48 for import prices and 0.63 for export prices. Moreover, this imperfect correlation is found using world prices that either include or exclude tariffs. These low price correlations suggest that domestic markets are not perfectly integrated with world markets and that tariff and world price changes are not fully transmitted to domestic prices. Imperfect transmission appears evident for manufacturing and service sectors as well as for agricultural sectors.

Arguably, inflation may be a more important factor in determining domestic prices than are world market prices. The correlation between the Consumer Price Index (CPI) and sectoral prices is much higher, at 0.92 , than the correlation between border and domestic prices. Recent inflation experience from 2008 may be related to an increased level of openness to the world economy, and may be driven in part by events abroad such as global recession and the collapse of world trade, with recovery abroad raising inflation again (Riedel 2009). It is also likely (Abbott and Tarp 2012) that domestic stimulus measures have contributed to the recent inflation experiences.

With data on world prices, tariffs and domestic prices, price transmission modeling can be relied on to measure both the extent of market integration and the use of trade policy to stabilize and block price transmission. Moreover, price transmission is at the heart of any meaningful quantification of the impact of policy reforms. By building the estimates of price transmission elasticities into partial or general equilibrium models, the extent to which world price changes may pass through borders can be established. The specific aim here is to provide estimates of price transmission elasticities from the world market to the domestic market in sectors encompassing the tradable portion of the Vietnamese economy. An alternate hypothesis investigated here is that non-neutral inflation drives domestic prices. Our study takes advantage of an investment, trade and price database obtained from Vietnam's General Statistical Office (GSO 2009). These data are supplemented with macroeconomic information extracted from International Financial Statistics (IFS 2011). Annual price and inflation data are analyzed by testing for the LOP and examining neutral inflation pass-through.

Our detailed results point to the need for estimating the price transmission elasticities at disaggregated level for trade policy analysis to be informative. Low transmission elasticities mute tariff impacts, implying that traditional trade policy analysis often exaggerates the effects of change in world market prices, exchange rates and tariffs on the domestic economy. We recall that institutional reform, market access openings overseas, and incentives for foreign investment play a critical role in trade policy, as was 
evident in the evolution of Vietnam's WTO accession negotiations. While negotiators were very well aware of these aspects, standard tariff reforms continued to be in focus in stylized research efforts that were largely off-target. Arguably, the existing approach in mainstream trade policy analysis is in need of revision, and much can be learnt in this regard from studying the Vietnamese case.

\section{Empirical Design}

The relationship between domestic and world prices under the LOP can formally be written as,

$$
P_{k t}^{d}=e_{t}^{n} P_{k t}^{w^{\prime}}\left(1+T_{k t}\right)\left(1+\tau_{k t}\right)
$$

where $P_{k t}^{d}$ denotes the domestic price for sector $k$ in time $t, P_{k t}^{w^{\prime}}$ the world price expressed in foreign currency for sector $k$ in time $t, e_{t}^{n}$ the nominal exchange rate in units of home currency per unit of foreign currency in time $t, T_{k t}$ the ad-valorem tariff rate for sector $k$ in time $t$, and $\tau_{k t}$ transportation and transactions costs (as a percentage of the landed import price) for sector $k$ in time $t$. In addition, deflating the nominal exchange rate by relative price levels yields a measure of the real exchange rate:

$$
e_{t}^{r}=e_{t}^{n} * \frac{C P I_{F t}}{C P I_{H t}}
$$

where $e_{t}^{r}$ is the real exchange rate in time $t$, and $C P I_{H t}$ and $C P I_{F t}$ are consumer price indices in the home country and foreign country in time $t$, respectively. Substituting (2) into (1) gives

$$
P_{k t}^{d}=\left(e_{t}^{r} * \frac{C P I_{H t}}{C P I_{F t}}\right) P_{k t}^{w^{\prime}}\left(1+T_{k t}\right)\left(1+\tau_{k t}\right)=P_{k t}^{w}\left(1+\tau_{k t}\right)
$$

where $P_{k t}^{w}=\left(e_{t}^{r} * \frac{C P I_{H t}}{C P I_{F t}}\right) P_{k t}^{w^{\prime}}\left(1+T_{k t}\right)$ denotes the tariff-inclusive world price, measured 
in home currency. This relationship can be captured by the following simple regression model:

$$
P_{k t}^{d}=\beta_{k} P_{k t}^{w}+\varepsilon_{k t}
$$

where $\varepsilon_{k t}$ is the error term and $\beta_{k}$ is the transmission coefficient, measuring to what extent world prices are transmitted into the domestic market. $\beta_{k}=1$ if the LOP holds and transportation and transaction costs, $\tau_{k t}$, are small. This relationship uses the world price as measured in the GSO data on sectoral border prices, the tariff inclusive home currency form.

The empirical models presented in what follows were developed based on Equations (1) (4). Two groups of price transmission models, level regressions and first-difference regressions, are estimated. In the first group of models, the dependent variable in logarithmic form is directly regressed on independent variables, and in the second group of models, all the variables are taken as first differences. Specifically, the first group of models include the following two equations:

$$
\begin{gathered}
\ln P_{k t}^{d}=\mu_{k}+\beta_{k} \ln P_{k t}^{w}+\varepsilon_{k t} \\
\ln P_{k t}^{d}=\mu_{k}+\beta_{k} \ln P_{k t}^{w}+\alpha_{k} \ln C P I_{H t}+\varepsilon_{k t}
\end{gathered}
$$

where $P_{k t}^{d}$ denotes domestic price in sector $k$ in time $t, P_{k t}^{w}$ the tariff-inclusive world price in home currency in sector $k$ in time $t, C P I_{H t}$ the consumer price index in Vietnam in time $t$, and $P_{k t}^{w}$ is the error term. The coefficient estimates on logarithmic independent variables can be interpreted as elasticities.

The first model is a level regression, only including world price as the independent variable, which is a direct logarithmic regression model based on Equation (4). The estimation results for this simple specification can be used to test the LOP in the short run and to compare with the results from other model specifications to assess how much new information is offered by additional independent variables and allowing for dynamic adjustments.

The second model adds the domestic CPI to the first model to test if domestic inflation has had a more important impact on sectoral domestic price variation than through the transmission of nominal, currency adjusted world prices, and if the passthrough of inflation is neutral across sectors. Since $P_{k t}^{w}$ and $P_{k t}^{d}$ are both nominal prices, in principle the effects of neutral inflation are already incorporated into the first 
level regression model as well. Based on the direct relationship between $P_{k t}^{w}$ and ${ }_{k t}$ in Equation (3), we can infer that if the transmission elasticity $\beta_{k}=1$ in the first level regression, then the correlation between the sectoral domestic price and the CPI in the home country is one-to-one, hence inflation pass-through is neutral. Equation (6) allows for the possibility that inflation pass-through is not neutral.

In the following discussions, the first model, Equation (5), is referred to as the level model without inflation, and the second model, Equation (6), is referred to as the level model with inflation.

These series may be non-stationary or serially correlated. Facing these potential problems, first-difference models, particularly with an error correction term in two specifications below, are employed (Baffes and Gardner 2003). Since we have very short time series available, testing for cointegration and stationarity in the underlying price series, and estimating their order, are not practical. While we cannot be certain without these tests whether moving to a first difference model is necessary, both level models and first difference models were estimated. Results are qualitatively very similar and behave as expected when moving between these two specifications. Parameter estimates for price transmission are somewhat lower in first difference models, but inflation effects are quite stable.

The mathematical expressions of the second group of empirical models are

$$
\begin{gathered}
\left(P_{k t}^{d}-P_{k t-1}^{d}\right)=\mu_{k}+\theta_{k}\left(P_{k t}^{w}-P_{k t-1}^{w}\right)+\varepsilon_{k t} \\
\left(P_{k t}^{d}-P_{k t-1}^{d}\right)=\mu_{k}+\gamma_{k}\left(P_{k t-1}^{w}-P_{k t-1}^{d}\right)+\theta_{k}\left(P_{k t}^{w}-P_{k t-1}^{w}\right)+\varepsilon_{k t} \\
\left(P_{k t}^{d}-P_{k t-1}^{d}\right)=\mu_{k}+\gamma_{k}\left(P_{k t-1}^{w}-P_{k t-1}^{d}\right)+\theta_{k}\left(P_{k t}^{w}-P_{k t-1}^{w}\right)+\alpha_{k}\left(C P I_{H t}-C P I_{H t-1}\right)+\varepsilon_{k t}
\end{gathered}
$$

The third model, Equation (7) is a strict first difference form of the level regression without inflation. The fourth model, Equation (8) is the standard error correction model. The cointegration term of the error correction model is $P_{k t-1}^{w}-P_{k t-1}^{d}$. The longrun cointegrating coefficient $\beta_{k}$, or long run price transmission elasticity, is assumed to equal one here as in Baffes and Gardner (2003), so long-run convergence to the LOP is assumed. If both $\gamma_{k}$ and $\theta_{k}$ are equal to zero, the term of long-run convergence to the LOP vanishes, and violation of long run LOP can be inferred. The fifth model, shown 
in Equation (9) is the error correction model with an inflation term. Coefficient $\alpha_{k}$ indicates the degree to which inflation passes through in sector $k$. If both $\gamma_{k}$ and $\theta_{k}$ are equal to zero, this model specification turns into a regression of the relationship between the domestic price and inflation - in first differences.

In what follows, the third model is referred to as the first difference model without inflation, the fourth model as the Error Correction Model (ECM), and the fifth model as ECM with inflation.

Not all of the first-difference models are in logarithmic form. The difference terms may be negative for certain years and certain sectors, hence logarithms would be undefined. Since all indices in the base year are equal to 100 , the coefficients on the difference terms are still elasticities if base-year levels are used in computing elasticities. Thus, we may interpret $\theta_{k}$ as the approximate short run price transmission elasticity in these specifications.

The CPI is a weighted average of sectoral domestic prices, so might be endogenous for sectors with large weights (sectoral shares of output). Therefore, we performed the Durbin-Wu-Hausman endogeneity test on the inflation term. We used a policyset interest rate and monetary reserves, both monetary policy variables available from the IMF (2011), as instruments for the inflation term, CPI. The test results indicate that there is no statistically significant endogeneity issue on the inflation term for all sectors. The statistical test results are consistent with the notion that each individual sector only account for a small portion of the economy and the influence of individual sectoral price on overall price is small. The Section IV estimation results using the two instruments for CPI are also very similar to the OLS results without instruments, confirming that the inflation term does not exhibit a significant endogeneity problem.

In addition to normal significance tests against zero for all the parameters, a couple of other hypotheses can be tested from the above models. The first hypothesis concerns the extent of price transmission and so validity of LOP in each sector. If LOP holds, it suggests co-movement between domestic and world prices and perfect market integration in the sector, hence $\theta_{k}=1$.

Also, the question regarding whether or not inflation is neutrally transmitted into different sectors can be addressed. When the transmission coefficient $\theta_{k}$ is insignificant, the world price does not bring inflationary pressure. Neutral inflation pass-through implies in this case that the inflation coefficient $\alpha_{k}$ equals unity. When the transmission coefficient $\theta_{k}$ is significantly different from zero but not significantly different from one, neutral inflation pass-through implies that the inflation coefficient $\alpha_{k}$ equals zero. If 
$\theta_{k}=1, \alpha_{k}=0$, inflation pass-through is non-neutral. However, if $\theta_{k} \neq 1$, then the neutrality of inflation pass-through is dependent on the magnitude of $\alpha_{k}$. Inflation pass-through is only neutral if $\theta_{k}+\alpha_{k}=1$.

\section{Data}

For this study, we assembled annual time series data on prices and inflation over the years from 1999 to 2008 for Vietnam. All the data are indices with 1999 as the base year. The price series were obtained from the GSO (2009). Domestic prices $P_{k t}^{d}$ are as received by producers. World prices $P_{k t}^{w}$ are export prices for the exporting sectors, and are import prices for the importing sectors. The world prices from the GSO are tariff inclusive and measured in local currency (Dong), corresponding with the term $P_{k t}^{w}$ in Equations (4) (9). In addition, the distinction between exporting sectors and importing sectors are not free from ambiguity due to the presence of two-way trade flows in most sectors. The classification of sectors' trade status follows Boys (2008), and her classification is based on the dominant direction of the trade flows during the period from 2000 to 2005 . The inflation level, $C P I_{H t}$ is measured by consumer price indices from IMF (2010).

We relied on three levels of sectoral aggregations to estimate these models. The first level includes 87-sectors, which are the traded-sectors from the 112-sector aggregation typically used by GSO. The 25 service sectors are not included in this analysis because they are viewed by GSO as non-traded sectors and hence no sectoral data on export and import prices are reported.

At the second level of aggregation, the 87 sectors were mapped into 24 sectors as in Abbott et al. (2008), a typical CGE modeling practice. The 24-sector aggregated export and import prices are averages weighted by trade values. Similarly, aggregated domestic prices were calculated as averages weighted by gross output levels of the 87-sectors. Both trade and output data are from GSO (2009).

The third level of aggregation consists of five sectors: agricultural exports, agricultural imports, manufacturing exports, manufacturing imports, and the import of energy and resources. This level of aggregation was developed mainly for presentation purposes and for examining whether estimation efficiency could be achieved by pooling similar sectors into this high level of aggregation. Panel regressions were run for each of these 
five categories. Those panel regressions replicate the pooling strategy employed in Abbott et al. (2010) that resulted in very low price transmission elasticity estimates. We employed both fixed effect and random effect models for panel regressions. Since no substantive differences were found between these two types of models, we only report estimation results for the random effect models here.

\section{Results}

Four sets of results emerge - on (i) aggregation bias and pooling, (ii) the extent of imperfect price transmission, (iii) the speed of adjustment to long run LOP, and (iv) inflation neutrality. Only key results are discussed for reasons of space.

\section{A. Aggregation and pooling}

Large sectoral variation exists in the extent of imperfect world price transmission. Moreover, regressions need to be at an 87-sector aggregation level to avoid generating biased price transmission estimates that are unhelpful in subsequent trade policy modelling.

Variation exists across sectors regardless of model specification. For example, the elasticity of price transmission for each sector, measured by the parameter $\theta_{k}$ in the short run and $\beta_{k}$ in the long run, ranges widely. The means and standard deviations of estimated price transmission elasticities are shown in Table 1. The standard deviations are often more than twice the mean levels, suggesting high variance across sectors. This pattern is exhibited for all model specifications and for all aggregation levels investigated in this study.

\footnotetext{
${ }^{1}$ Econometric results from all models, and at all levels of aggregation, are available from the authors upon request.
} 
Table 1. Estimated price transmission elasticities

\begin{tabular}{|l|c|c|c|c|c|c|}
\hline \multirow{2}{*}{ Model specification } & \multicolumn{2}{|c|}{$\begin{array}{c}\text { 5-sector } \\
\text { aggregation }\end{array}$} & \multicolumn{2}{c|}{$\begin{array}{c}\text { 24-sector } \\
\text { aggregation }\end{array}$} & \multicolumn{2}{c|}{$\begin{array}{c}\text { 87-sector } \\
\text { aggregation }\end{array}$} \\
\cline { 2 - 7 } & Mean & $\begin{array}{c}\text { Standard } \\
\text { deviations }\end{array}$ & Mean & $\begin{array}{c}\text { Standard } \\
\text { deviations }\end{array}$ & Mean & $\begin{array}{c}\text { Standard } \\
\text { deviations }\end{array}$ \\
\hline $\begin{array}{l}\text { Level model without } \\
\text { inflation }\end{array}$ & 0.25 & 0.23 & 1.14 & 1.33 & 0.87 & 1.87 \\
\hline Level model with inflation & -0.16 & 0.27 & 0.08 & 0.86 & 0.00 & 0.98 \\
\hline $\begin{array}{l}\text { First difference model } \\
\text { without inflation }\end{array}$ & 0.20 & 0.32 & 0.93 & 2.05 & 1.03 & 1.66 \\
\hline Error Correction Model & -0.02 & 0.03 & 0.05 & 0.57 & 0.65 & 1.78 \\
\hline $\begin{array}{l}\text { Error Correction Model } \\
\text { with inflation }\end{array}$ & -0.01 & 0.02 & 0.28 & 0.44 & 0.40 & 1.13 \\
\hline
\end{tabular}

(Note) The means and standard deviations reported here are simple, un-weighted measures from the sectoral estimates for each model.

Pooling was tried to achieve estimation efficiency given the short sample, but the aggregated regressions are hardly sufficient enough to represent the transmission of world prices for all the sectors within an aggregated group. Moreover, the parameter estimates of the 5-sector panel regressions appear to be biased downward. Using aggregated data leads to errors in measuring the pass-through of world to domestic prices for a given sector, and results in underestimation of the relevant parameter. The level regression without inflation, in which the world price is the only independent variable, can serve as an illustration of this aggregation bias. We take the agricultural export sectors as an example, and the results of the level regression model without inflation are summarized in the first two columns in Table 2. The aggregated agricultural export sector at the 5-sector aggregation level has a transmission coefficient smaller than the parameter estimates for all of the sectors at the 24-sector aggregation level (i.e., 0.34 compared with $0.92,0.43,0.52,1.74$, and 1.35). Similar results are found for the other highly aggregated categories. 


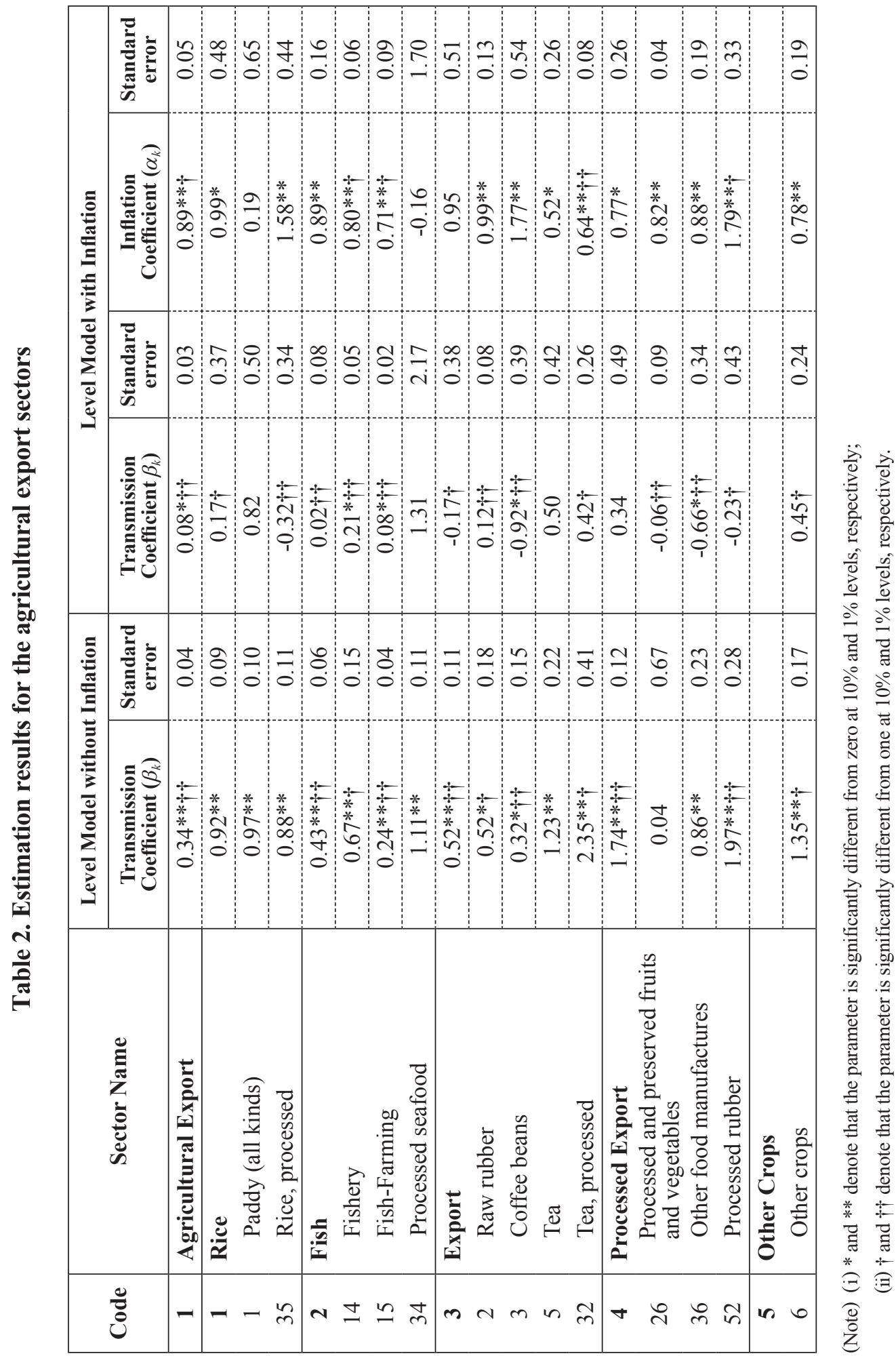


The parameter estimates at the 24-sector level tend to be dominated by the largest sector, and thus are unable to be a representative estimate for the entire aggregated sector. There is less evidence of simple downward aggregation bias, but significant differences across sub-sectors within a sector are found. As shown in Table 2, in the agricultural export sector, for example, the transmission elasticity at the 24-sector aggregation level is 0.52 , which is equal to the elasticity estimate for raw rubber, but less than one half of the parameter estimate for tea (1.23), and less than one fourth of the parameter estimate for processed tea (2.35). The elasticity for coffee is lower than any of these, at 0.32 .

The differences in parameter estimates between various aggregation levels signal the danger of only running regressions on aggregated price data and using uniform price transmission elasticities for all the sectors in the aggregated groups. This may lead to biased results in policy assessment. The disaggregated 87 sectoral regressions are more revealing. For example, if we wish to calculate effects of tariff changes on domestic prices, much smaller impacts are found using aggregated sector transmission elasticities than when disaggregated tariffs and transmission elasticities are used.

\section{B. Price transmission}

The estimation results show imperfect price transmission in most sectors. This may be an indicator of limited integration between domestic and world markets and additional regressions did not reveal trade policy systematically separating domestic and world prices. Long-run convergence to the LOP does not hold for most sectors.

Despite the quantitative differences in the parameter estimates on transmission elasticities, the regression results at all aggregation levels univocally show imperfect price transmission and relatively insensitive domestic price responses to world price changes. This is demonstrated by price transmission elasticities significantly less than unity in most cases. Nevertheless, the price transmission elasticities are significantly above zero for most sectors as well. The fact that the transmission elasticities are different from both zero and one suggests a certain level of imperfect, partial transmission from world to domestic prices. However, price transmission is not frictionless or instantaneous.

The wide sectoral variation in terms of the estimated transmission elasticities begs two questions: which sectors are integrated into the world market, and which sectors are segmented from the world market. These questions are answered based on the estimation results for the Error Correction Model (ECM) with inflation model Equation (9). Table 
3 shows the results of this model for agricultural export sectors. Among these sectors, many of the estimated transmission elasticities are not significantly different from zero, and several sectors turn from positive transmission elasticities in the models without the inflation term to negative elasticities when the inflation term is included. 


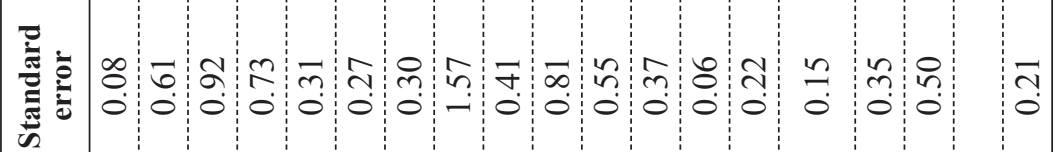

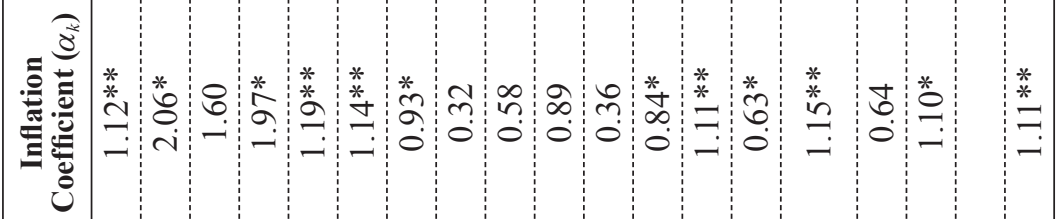

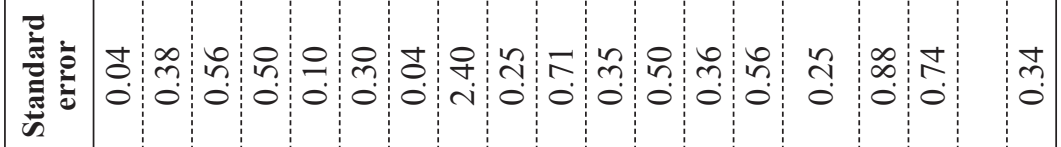

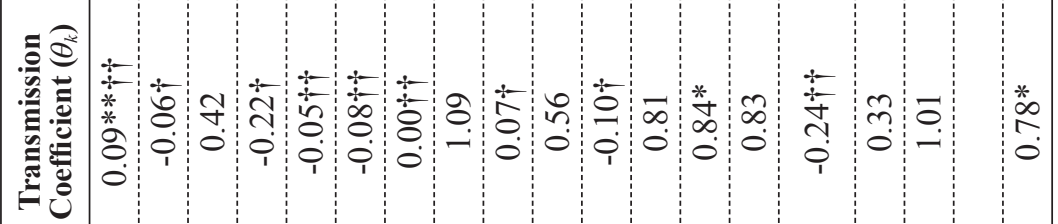

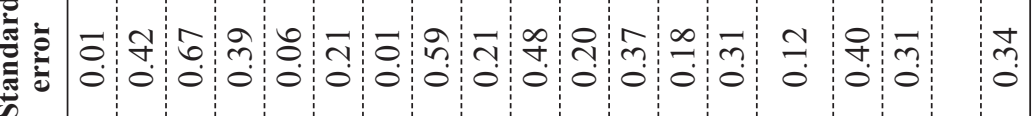
$\overline{7}$ क 
We further classified all the sectors into two categories based on the results from the ECM with inflation model. If the estimated price transmission elasticity $\theta_{k}$ is significantly different from zero but not from one, it can be categorized as an integrated sector. If the estimated short run price transmission elasticity $\theta_{k}$ is significantly different from one but not from zero, the sector is labeled as a segmented sector. ${ }^{2}$ Intermediate cases correspond with significant but imperfect price transmission.

The results of these classifications are summarized in Table 4. In the exporting agricultural sectors, only the sectors of processed tea and other crops are closely linked with the world market, whereas importing agricultural sectors producing sugar, pigs, processed vegetables, animal oils, and fats are closely integrated with the world market. Among manufacturing export sectors, those sectors producing carpet and processed wood and other wood products can be classified as integrated sectors. Seven out of 40 manufacturing import sectors are integrated with the world market, and four of the integrated sectors produce chemical products. In total, only 14 of 87 sectors pass this test on market integration. Only $15 \%$ of agricultural export sectors, $18 \%$ of agricultural import sectors, $40 \%$ of manufacturing export sectors, and $18 \%$ of manufacturing import sectors are categorized as integrated sectors.

\footnotetext{
${ }^{2}$ We also consider sectors to be segmented if coefficients are significantly less than zero, hence incorrectly signed. Moreover, if a coefficient is significantly less than zero, it must also be significantly less than one.
} 
Table 4. Integrated and segmented sectors

\section{A. Integrated sectors}

\begin{tabular}{|c|l|c|}
\hline Code & \multicolumn{1}{|c|}{ Sector Name } & $\begin{array}{c}\text { Transmission } \\
\text { Coefficient }\left(\theta_{k}\right)\end{array}$ \\
\hline 32 & Tea, processed & 0.84 \\
\hline 6 & Other crops & 0.78 \\
\hline 30 & Sugar, refined & 3.50 \\
\hline 7 & Pigs (All kinds) & 1.56 \\
\hline 23 & Processed vegetable, and animal oils and fats & 1.64 \\
\hline 78 & Carpets & 1.83 \\
\hline 44 & Processed wood and wood products & 1.08 \\
\hline 65 & General -purpose machinery & 0.61 \\
\hline 40 & Cement & 0.74 \\
\hline 45 & Basic organic chemicals & 0.78 \\
\hline 46 & Basic inorganic chemicals & 1.78 \\
\hline 59 & Other chemical products & 0.83 \\
\hline 56 & Other plastic products & 0.72 \\
\hline 68 & Automobiles & 3.63 \\
\hline & & \\
\hline
\end{tabular}




\section{B. Segmented sectors}

\begin{tabular}{|c|c|c|}
\hline Code & Sector Name & $\begin{array}{c}\text { Transmission } \\
\operatorname{Coefficient}\left(\theta_{k}\right)\end{array}$ \\
\hline 35 & Rice, processed & -0.22 \\
\hline 14 & Fishery & -0.08 \\
\hline 15 & Fish-Farming & 0.00 \\
\hline 3 & Coffee beans & -0.10 \\
\hline 26 & Processed and preserved fruits and vegetables & -0.24 \\
\hline 82 & Animal feeds & -0.11 \\
\hline 9 & Poultry & 0.08 \\
\hline 24 & Milk, butter and other dairy products & -0.16 \\
\hline 27 & Alcohol, beer and liquors & -0.84 \\
\hline 33 & Cigarettes and other tobacco products & 0.00 \\
\hline 80 & Products of leather tanneries & 0.03 \\
\hline 81 & Leather goods & -0.99 \\
\hline 64 & Bicycles and spare parts & -0.13 \\
\hline 66 & Other general-purpose machinery & -0.55 \\
\hline 70 & Electrical machinery & -1.04 \\
\hline 71 & Other electrical machinery and equipment & -1.10 \\
\hline 47 & Chemical fertilizer & 0.00 \\
\hline 49 & Pesticides & -1.17 \\
\hline 54 & Perfumes and other toilet preparation & -3.65 \\
\hline 62 & Home appliances and its spare parts & -1.22 \\
\hline 73 & Non-ferrous metals and products (except machinery equipment) & -0.02 \\
\hline 74 & Ferrous metals and products (except machinery equipment) & -0.04 \\
\hline 76 & Fibers, thread (all kinds) & 0.00 \\
\hline 72 & Machinery used for broadcasting, television and information activities & -0.62 \\
\hline 63 & Motor vehicles, motor bikes and spare parts & -0.46 \\
\hline 67 & Other special -purpose machinery & -1.31 \\
\hline 69 & Other transport means & -0.76 \\
\hline 84 & Products of publishing house & -2.00 \\
\hline 86 & Gasoline, lubricants (already refined) & -0.21 \\
\hline 87 & Electricity, gas & 0.01 \\
\hline
\end{tabular}

(Note) (i) Integrated sectors have a price transmission elasticity $\theta_{k}$ significantly different from zero but not from one.

(ii) Segmented sectors have a $\theta_{k}$ significantly different from one but not from zero. The significance level for this classification is $10 \%$. 
At the other extreme, 30 sectors are segmented from the world market, as the transmission elasticities are close to zero. Among those sectors, some are intermediate goods for processed products, which are less connected with the world market relative to their corresponding final goods. Electricity and gas are products under heavy protection, and their domestic prices are often decoupled from world prices. In addition, some products such as animal feeds, alcohol, beer and liquor, and cigarettes and other tobacco products are less traded with the rest of the world, and hence have low levels of price transmission. $38 \%$ of agricultural export sectors, $33 \%$ of agricultural import sectors, $20 \%$ of manufacturing export sectors, $35 \%$ of manufacturing import sectors, and $100 \%$ of energy import sectors are classified as segmented.

Intermediate cases are neither integrated nor segmented. They exhibit imperfect price transmission. This was the case for $47 \%$ of agricultural export sectors, $49 \%$ of agricultural import sectors, $40 \%$ of manufacturing export sectors and $47 \%$ of manufacturing import sectors.

Except for manufacturing export sectors, all the other sectors exhibit a higher percentage of sectors classified as segmented, rather than integrated. Manufacturing export sectors have the largest proportion of sectors classified as integrated, and a high share of sectors that exhibit imperfect transmission - that is similar to other aggregate categories. In the panel regressions, this is the only highly aggregated sector that showed sizeable world price transmission.

\section{Speed of adjustment}

The ECM and the ECM with inflation models include the speed of adjustment coefficient $\gamma_{k}$. It may be used to test whether price transmission is complete in the long run, even if it is not in the short run. If these parameters are significant, the LOP holds in the long run, as domestic prices converge to world prices. Taking the agricultural export sector results in Table 3, for example, the adjustment parameter is significant for only three sectors, demonstrating the lack of convergence to the LOP in the long run for the majority of the agricultural export sectors.

Table 5 shows all of the sectors that have significant speed of adjustment parameters in the ECM with inflation. The speed of adjustment parameter is not significantly different from zero for most sectors (67 sectors in the ECM with inflation model), which indicates no significant adjustment made in the short run in order to converge to the LOP. Among 
those few sectors with speed of adjustment parameters significantly different from zero, half of them are classified as integrated sectors as indicated by the transmission elasticities, implying that well integrated sectors tend to eliminate the wedge between world and domestic prices relatively quickly. Domestic prices closely follow world prices, and the convergence to the LOP can be fulfilled during a relatively short time period in those few sectors. Most sectors appear disconnected from world prices, based on this measure as well as on price transmission elasticities. Alternatively, for most sectors the speed of adjustment to the LOP is very low.

Table 5. Sectors with long-run convergence to the law of one price

\begin{tabular}{|c|l|c|}
\hline Code & \multicolumn{1}{|c|}{ Sector Name } & $\begin{array}{c}\text { Speed-of-Adjustment } \\
\text { Coefficient }\left(\gamma_{k}\right)\end{array}$ \\
\hline 5 & Tea & 0.85 \\
\hline 32 & Tea, processed & 0.64 \\
\hline 6 & Other crops & 0.73 \\
\hline 4 & Sugarcane & 0.77 \\
\hline 30 & Sugar, refined & 1.43 \\
\hline 7 & Pigs (All kinds) & 2.41 \\
\hline 8 & Cattle (All kinds) & 1.24 \\
\hline 29 & Non-alcohol water and soft drinks & 0.95 \\
\hline 78 & Carpets & 0.48 \\
\hline 79 & Weaving and embroidery of textile -based goods (except carpets) & 0.72 \\
\hline 44 & Processed wood and wood products & 0.45 \\
\hline 39 & Bricks, tiles & 0.47 \\
\hline 43 & Paper pulp and paper products and by products & 1.26 \\
\hline 45 & Basic organic chemicals & 0.81 \\
\hline 46 & Basic inorganic chemicals & 0.50 \\
\hline 48 & Fertilizer & 0.91 \\
\hline 58 & Ink, varnish and other painting materials & 0.43 \\
\hline 59 & Other chemical products & 0.39 \\
\hline 61 & Precise and optics equipment, meter (all kinds) & 1.12 \\
\hline 68 & Automobiles & 0.85 \\
\hline & & \\
\hline
\end{tabular}

(Note) (i) Sectors in the table have significant adjustment coefficients in the error correction model with inflation.

(ii) The significance level for this classification is $10 \%$. 


\section{Inflation}

The effect of inflation varies widely across sectors, with some sectors bearing strong pressure while others are only slightly affected by inflation. Despite this variation, inflation is better at explaining domestic prices than is the world price.

Table 1 also shows the importance of inflation as an explanatory variable for domestic prices, and that price transmission estimates diminish greatly once inflation is explicitly included. ${ }^{3}$ In the case of the level regression models, the average of price transmission elasticity estimates falls from about one to nearly zero when inflation is taken into account.

The level regression with inflation model is one of the two models including the inflation rate as a separate independent variable, the estimation of which illustrates the importance of including inflation explicitly. The third to the sixth columns of Table 2 report estimation results of the level regression with the inflation variable added for the agricultural export sectors. Large variation in the magnitude of the inflation parameter $\alpha_{k}$ indicates that the effect of inflation varies across sectors. For example, in the agricultural export sectors, the inflation coefficient $\alpha_{k}$ is only 0.52 for the tea sector, whereas it reaches 1.79 for the processed rubber sector. Nonetheless, one similarity across sectors is that inflation has a positive impact on domestic prices in almost all 83 sectors at the 87-sector aggregation level. Also, only seven sectors at the 87-sector aggregation level have insignificant inflation parameters. The inflation parameters for all the other sectors are significantly different from zero at the $10 \%$ or $1 \%$ level. By contrast, 50 sectors at the 87-sector aggregation level have insignificant long run price transmission coefficients in the level regression model with inflation. Moreover, when adding the inflation rate to the model, the price transmission elasticities $\left(\theta_{k}\right)$ fall dramatically. This suggests that the inflation component in world prices $\left(P_{k t}^{w}\right)$ picks up much of the information that is useful in explaining the variation of domestic prices. The results are consistent with the notion that the domestic market is not fully connected with the world market for many sectors, and sectoral prices are still dominantly affected by the domestic inflation rate rather than prices on the world market.

In order to test for the neutrality of inflation pass-through, the coefficient on inflation can be compared against one when the transmission coefficient is not significantly

\footnotetext{
3 Both world and domestic prices are nominal, so in principle inflation is already captured in the price transmission relationship. But when world prices are disconnected from domestic prices, and inflation is an important determinant of domestic prices, the CPI needs to be included in the regression.
} 
different from zero, and can be compared against zero when the transmission coefficient is not significantly different from one. The sectoral classifications of neutral versus non-neutral inflation pass-through are summarized in Table 6. The reference model for this classification is the ECM with inflation model, so short run price transmission is considered for these tests. Many results are consistent with neutral inflation passthrough. At the 87-sector aggregation level, 30 sectors show neutral inflation passthrough, while 12 sectors show clearly non-neutral inflation pass-through according to this criterion. Some sectors, such as cattle and paper pulp sectors, tend to be hit more severely by inflation, while others such as the animal feed sector, and food sector producing cakes, jams, candy, cocoa, and chocolate products show a lower level of price increase than overall inflation. For the other 45 sectors the neutrality of inflation passthrough is ambiguous. Moreover, significance tests on individual parameters, $\theta_{k}$ and $\alpha_{k}$, are not sufficient. The test on $H_{0}: \theta_{k}+\alpha_{k}=1$ is needed in this case to establish inflation neutrality. 


\section{Table 6. Neutrality of inflation pass-through}

\section{A. Sectors with neutral inflation pass-through}

\begin{tabular}{|c|c|c|}
\hline Code & Sector Name & $\begin{array}{c}\text { Inflation } \\
\text { Coefficient }\left(\alpha_{k}\right)\end{array}$ \\
\hline 35 & Rice, processed & 1.97 \\
\hline 14 & Fishery & 1.14 \\
\hline 15 & Fish-Farming & 0.93 \\
\hline 5 & Tea & 0.84 \\
\hline 26 & Processed and preserved fruits and vegetables & 1.15 \\
\hline 52 & Processed rubber and by products & 1.10 \\
\hline 4 & Sugarcane & 0.92 \\
\hline 10 & Other Livestock & 1.33 \\
\hline 22 & Processed, preserved meat and by-products & 0.91 \\
\hline 24 & Milk, butter and other dairy products & 1.29 \\
\hline 28 & Beer and liquors & 0.75 \\
\hline 31 & Coffee, processed & 0.76 \\
\hline 77 & Ready-made clothes, sheets & 0.61 \\
\hline 81 & Leather goods & 0.79 \\
\hline 70 & Electrical machinery & 0.87 \\
\hline 39 & Bricks, tiles & 1.33 \\
\hline 41 & Concrete, mortar, and other cement products & 1.35 \\
\hline 42 & Other building materials & 1.26 \\
\hline 48 & Fertilizer & 1.85 \\
\hline 54 & Perfumes and other toilet preparation & 0.71 \\
\hline 57 & Paint & 0.91 \\
\hline 58 & Ink, varnish and other painting materials & 1.35 \\
\hline 55 & Plastic (including semi-plastic products) & 1.41 \\
\hline 73 & Non-ferrous metals and products (except machinery equipment) & 0.78 \\
\hline 75 & Weaving of cloths (all kinds) & 0.68 \\
\hline 84 & Products of publishing house & 0.64 \\
\hline 86 & Gasoline, lubricants (already refined) & 2.33 \\
\hline 65 & General-purpose machinery & 0.46 \\
\hline 56 & Other plastic products & -0.14 \\
\hline 68 & Automobiles & 0.45 \\
\hline
\end{tabular}




\section{B. Sectors with non-neutral inflation pass-through}

\begin{tabular}{|c|l|c|}
\hline Code & \multicolumn{1}{|c|}{ Sector Name } & $\begin{array}{c}\text { Inflation } \\
\text { Coefficient }\left(\alpha_{k}\right)\end{array}$ \\
\hline 25 & Cakes, jams, candy, cocoa, chocolate products & 0.35 \\
\hline 61 & Precise and optics equipment, meter (all kinds) & 0.39 \\
\hline 79 & Weaving and embroidery of textile -based goods (except carpets) & 0.46 \\
\hline 82 & Animal feeds & 0.50 \\
\hline 66 & Other general -purpose machinery & 0.52 \\
\hline 29 & Non-alcohol water and soft drinks & 1.58 \\
\hline 9 & Poultry & 1.63 \\
\hline 47 & Chemical fertilizer & 1.73 \\
\hline 83 & Products of printing activities & 1.99 \\
\hline 27 & Alcohol, beer and liquors & 2.59 \\
\hline 8 & Cattle (All kinds) & 3.66 \\
\hline 43 & Paper pulp and paper products and by products & 3.82 \\
\hline
\end{tabular}

(Note) (i) The significance level for this classification is $10 \%$.

(ii) The reference model for this classification is the error correction model with inflation.

\section{E. Robustness checks}

In addition to the model specifications discussed above, we have explored three alternative model specifications. In the alternative error correction models, we included the real effective exchange rate, a wage index, and the tariff index as additional independent variables. The purpose of constructing these alternative model specifications is to examine if other theories may apply when the LOP fails. In principle, Equations (5) (9) restrict the exchange rate, world prices, and tariffs all to have the same effect on domestic prices, while alternative specifications examine whether these effects may somehow differ. The results from alternative specifications suggest that the CPI better explains prices than wages, implying that demand-pull inflation is more important than cost-push inflation. The divergence from the LOP seems not due to home goods effects, evidenced by an insignificant real exchange rate term in virtually all cases. Stabilization 
policy at the border also seems not to be a significant factor. The role of trade policy has already been captured by the world price for most sectors. Trade policy, at least working through tariff changes, does not have a separate measureable impact on domestic prices.

\section{Conclusions}

During the past 25 years, Vietnam has increasingly engaged with the world market through international trading agreements, altered border policies, institutional reforms, and promoting foreign investments. Development has picked up, so Vietnam has seen GDP growth, poverty reduction, expanding trade, increasing foreign investment, and periods of high inflation. While the IMF (2006) suggests that globalization should restrain inflation, our results imply that the linkages between domestic and world prices may be too weak for that to be the case.

We explored in detail how increasing world market integration and inflation impacted on domestic prices in Vietnam from 1999 to 2008. Specifically, we investigated the degree to which world price changes were transmitted into the domestic market and the level of sectoral inflation pass-through. We found that large sectoral variation exists in world price transmission. Panel regressions at a 5-sector aggregation level are unable to adequately represent the transmission mechanism of individual sectors in each group and suffer from aggregation bias. The 24-sector aggregation results are dominated by the largest sector, and thus the estimates are not representative for individual sectors within the aggregated group. Sectoral regressions at 87-sector aggregation level are needed to avoid these biased price transmission estimates.

The estimation results show imperfect price transmission in most sectors. This may indicate limited integration between domestic and world markets. Long-run convergence to the LOP does not hold for most sectors. Moreover, only 12 of 87 sectors show clearly non-neutral inflation pass-through. The effect of inflation varies widely across sectors, with some sectors bearing strong pressure while others are only slightly affected by inflation. Despite the variation across sectors, inflation is better at explaining domestic prices than are world prices. This is consistent with the observation that the connection between domestic and world prices remains limited for most sectors.

These results suggest that traditional trade policy analysis has often exaggerated the 
effects of changes in world market prices, exchange rates, and tariffs on the domestic economy. In impact analyses regarding trade reforms, tariff reduction effects have been an overriding concern for researchers, largely due to its modeling simplicity. Yet, our study found that tariff impacts are muted by low price transmission elasticities. Rather, institutional reform, market access openings, and incentives for foreign investment have played a more important role in trade integration than traditional tariff policy. In Vietnam's WTO accession process, negotiators' emphasis on other aspects of policy reforms such as minimum wages, which affect domestic prices through market wages and hence inflation, echoes our results of limited tariff effects on domestic prices. Regarding the sensible trade policy analysis, a disaggregated approach is required, and careful attention must be paid to how inflation influences the economy. Finally, more indepth research is called for on the relationship between an open Vietnamese economy and the mechanisms of inflation determination to improve macroeconomic policy management. This is a key policy concern as Vietnam moves to the next stage of its economic reform process after doi moi.

- Markets for most goods in Vietnam are imperfectly integrated with world markets. Hence, domestic factors play a key role in price determination.

- Tariff impacts in imperfectly integrated markets are muted.

- Price transmission elasticities measure the extent of market integration, and the relationship between domestic and world prices. Those parameters are measured in this paper, and are shown to vary widely across sectors, even at a disaggregated sectoral level.

- Policy makers need to take into account the extent of imperfect market integration in assessing policy changes that work through prices.

- The small country assumption, implicitly based on perfect market integration, overstates the linkage between domestic and world markets. Much of the research on WTO impacts in Vietnam, which utilized something close to this assumption and looked mostly at tariff changes, overstated the impact of economic integration on the Vietnamese economy.

- Models that use Armington imperfect substitution between domestic and imported goods in principle could account for imperfect market integration.

- Tariff impacts would be larger in sectors that are well integrated. The price transmission elasticities measured here show which sector are more likely to respond to tariff changes. 
- Manufacturing exports are the most closely integrated with world markets, while many are still weakly integrated. Imports of both manufactured and agricultural goods are less integrated.

- Price responses to tariff changes and other interventions occur with a lag. Long run responses over a considerable period are greater than immediate impacts, but long run responses may never reach fully integrated market expectations.

- Institutional changes, that encouraged Vietnam to rewrite business, trade and investment law, mattered much more than the tariff concession in Vietnam's WTO accession agreements. Market access abroad and incentives to foreign investment have also been more important than tariff adjustments.

- Vietnam has intermittently experienced rapid inflation, and prices responses have not been neutral, so relative prices have changed as inflation occurs.

- Controlling inflation through monetary policy will be more effective than border measures in achieving stable domestic prices.

Received 15 October 2013, Revised 15 August 2014, Accepted 2 October 2014

\section{References}

Abbott, Philip. "Modeling International Grain Trade with Government Controlled Markets." American Journal of Agricultural Economics 61 (1979): 22-31. doi:10.2307/ 1239496.

Abbott, Philip, Jeanet Bentzen, and Finn Tarp. "Trade and Development: Lessons from Vietnam's Past Trade Agreements.” World Development 37 (2009): 341-353. doi: 10.1016/j.worlddev.2008.04.005.

Abbott, Philip, Kathryn Boys, Pham Lan Huong, and Finn Tarp. "Trade and Development in Vietnam: Exploring Investment Linkages.” Technical Report, Central Institute of Economic Management (CIEM), Hanoi, Vietnam, 2008.

Abbott, Philip, Ce Wu, and Finn Tarp. "Vietnamese Trade and Development: Post WTO Accession." CIEM-Danida Working Paper, Central Institute of Economic Management (CIEM), Hanoi, Vietnam, 2010. 
Abbott, Philip and Finn Tarp. "Globalization Crises, Trade and Development in Vietnam." Journal of International Commerce, Economics and Policy 3, no. 1 (2012): 1-23. doi: 10.1142/S1793993312400066.

Abdulai, Awudu. "Using Threshold Cointegration to Estimate Asymmetric Price Transmission in the Swiss Pork Market." Applied Economics 34, no. 6 (2002): 679-687. doi: 10.1080/00036840110054035.

Alessandria, George. "International Deviations from the Law of One Price: The Role of Search Frictions and Market Share." International Economic Review 45, no. 4 (2004): 1263-1291. doi: 10.1111/j.0020-6598.2004.00305.x.

Anderson, Jemes, and Eric van Wincoop. "Trade Costs." Journal of Economic Literature 42, no. 3 (2004): 691-751. doi: 10.1257/0022051042177649.

Athukorala, Premachandra, and Jayant Menon. "Pricing to Market Behavior and Exchange Rate Pass-Through in Japanese Exports.” The Economic Journal 104, no. 423 (1994): 271-281. doi: 10.2307/2234748.

Atkeson, Andrew, and Ariel Burstein. "Pricing-to-Market, Trade Costs, and International Relative Prices." American Economic Review 98, no. 5 (2008): 1998-2031. doi: 10.1257/ aer.98.5.1998.

Baffes, John, and Bruce Gardner. "The Transmission of World Commodity Prices to Domestic Markets Under Policy Reforms in Developing Countries." The Journal of Policy Reform 6, no. 3 (2003): 159-180. doi: 10.1080/0951274032000175770.

Bautista, Romeo, Sherman Robinson, Finn Tarp, and Peter Wobst. "Policy Bias and Agriculture: Partial and General Equilibrium Measures." Review of Development Economics 5, no.10 (2001): 89-104. doi: 10.111/1467-9361.00109.

Boys, Kathryn. "Investment, Trade, and Economic Development: Lesson from Vietnam." PhD diss., Purdue University, 2008.

Bredahl, Maury, William Myers, and Keith Collins. "The Elasticity of Foreign Demand for U.S. Agricultural Products: The Importance of the Price Transmission Elasticity." American Journal of Agricultural Economics 61, no. 1 (1979): 58-63. http://www.jstor. org/stable/1239500.

Fafchamps, Marcel, and Ruth Hill. "Price Transmission and Trader Entry in Domestic 
Commodity Markets." Economic Development and Cultural Change 56, no. 4 (2008): 729-766. doi: 10.1086/588155.

Food and Agriculture Organization of the United Nations (FAO). The State of Food Insecurity in the World 2011. Rome, Italy: FAO, 2011.

Giovannini, Alberto. "Exchange Rates and Traded Goods Prices." Journal of International Economics 24, no. 1-2 (1988): 45-68. doi: 10.1016/0022-1996(88)900219.

Goldberg, Pinelopi and Michael Knetter. "Goods Prices and Exchange Rates: What Have We Learned?" Journal of Economic Literature 35, no. 3 (1997): 1243-1272. doi: $10.3386 / \mathrm{w} 5862$.

Goodwin, Barry and Matthew Holt. "Price Transmission and Asymmetric Adjustment in the U.S. Beef Sector." American Journal of Agricultural Economics 81, no. 3 (1999): 630-637. http://www.jstor.org/stable/1244026.

Gopinath, Gita,Oleg Itskhoki, and Roberto Rigobon. "Currency Choice and Exchange Rate Pass-Through.” American Economic Review 100, no.1 (2010): 304-336.doi:10.3386/ w13432.

General Statistics Office (GSO). Investment, Trade and Price Data for Vietnam. GSO, Hanoi, Vietnam, 2009.

General Statistics Office (GSO). Statistical Data. GSO, Hanoi, Vietnam, 2011. Accessed December 15, 2011. http://www.gso.gov.vn/default_en.aspx?tabid=491

Headey, Derek and Shenggen Fan. "Reflections on the Global Food Crisis." Washington, DC: International Food Policy Research Institute (IFPRI), 2010.

Hillberry, Russell and David Hummels. "Trade Elasticity Parameters for a Computable General Equilibrium Model.” In: Dixon, Peter and Dale Jorgenson (eds), Handbook of Computable General Equilibrium Modeling 1, no. 1. Amsterdam: North Holland, 2012.

International Monetary Fund (IMF). "How Has Globalization Affected Inflation?" chap. 3 in World Economic Outlook. (Washington DC:IMF, 2006), 97-134.

International Monetary Fund (IMF), International Financial Statistics. Washington DC: IMF, 2011. Accessed December 15, 2011. http://www.imfstatistics.org/imf/

Issard, Peter. "How Far Can We Push the 'Law of One Price?" The American Economic 
Review 67, no. 5 (1977): 942-948. http://www.jstor.org/stable?1828075.

Kinnucan, Henry and Olan Forker.. "Asymmetry in Farm-Retail Price Transmission for Major Dairy Products." American Journal of Agricultural Economics 69, no. 2 (1987): 285-292. doi: 10.2307/1242278

Knetter, Michael. "Why Are Retail Prices in Japan so High: Evidence from German Export Prices.” International Journal of Industrial Organization 15, no. 5 (1997): 549572. doi: 10.1016/S0167-7187(96)01021-1.

Krugman, Paul. "Pricing to Market When the Exchange Rate Changes." NBER Working Paper No. 1926, Cambridge, MA, 1986. http://www.nber.org/papers/w1926

Marston, Richard. "Pricing to Market in Japanese Manufacturing." Journal of International Economics 29, nos. 3-4 (1990): 217-236. doi: 10.1016/0022-1996(90) 90031-G

Menon, Jayant. "Exchange Rate Pass-Through." Journal of Economic Surveys 9, no. 2 (1995): 197-231. doi: 10.1111/j.1467-6419.1995.tb00114.x.

Miller, Douglas and Marvin Hayenga. "Price Cycles and Asymmetric Price Transmission in the U.S. Pork Market." American Journal of Agricultural Economics 83, no. 3 (2001): 551-562. doi: 10.1111/0002-9092.00177.

Miljkovic, Dragan. "The Law of One Price in International Trade: A Critical Review." Applied Economic Perspectives and Policy 21, no.1(1999):126-139. doi: 10.2307/ 1349976.

Nicita, Alessandro. "The Price Effect of Tariff Liberalization: Measuring the Impact on Household Welfare.” Journal of Development Economics 89, no.1 (2009): 19-27. doi: 10.1016/j.deveco.2008.06.009.

Rama, Martin and K.L. Sa. "Impacts of WTO Accession: Can they be Predicted? What to do about them?" In: Vietnam Development Report 2006: Business. Hanoi, Vietnam: World Bank Vietnam Office, 2005.

Riedel, James. "The Global Economic Crisis and Its Long-run Implications for Vietnam." United Nations Development Programme (UNDP), mimeo. Hanoi, Vietnam, September 2009.

Richardson, J. David. "Some Empirical Evidence on Commodity Arbitrage and the 
Law of One Price.” Journal of International Economics 8, no. 2 (1978): 341-351. doi: 10.1016/0022-1996(78)90027-2.

Rogoff, Kenneth, Kenneth Froot, and Michael Kim. The Law of One Price over 700 years. Washington, DC: International Monetary Fund, 2001.

Tyers, Rod and Kym Anderson. Disarray in World Food Markets: A Quantitative Assessment. Cambridge, England: Cambridge University Press, 1992.

von Cramon-Taubadel, Stephan. "Estimating Asymmetric Price Transmission With the Error Correction Representation: An Application to the German Pork Market. European Review of Agricultural Economics 25 no.1 (1998) 1-18. doi: 10.93/erae/25.1.

World Bank. World Development Indicators. Accessed December 16, 2012. Washington, DC: World Bank, 2012.

World Bank. Poverty Reduction in Vietnam: Remarkable Progress and Emerging Challenges. Washington, DC: World Bank, 2013. 